\title{
Asthma and COVID-19: What do we know?
}

\author{
Nurhan SARIOĞLU ${ }^{1}(I D)$
}

\author{
${ }^{1}$ Department of Chest Diseases, Faculty of Medicine, Balikesir University, \\ Balikesir, Turkey \\ ${ }^{1}$ Balıkesir Üniversitesi Tıp Fakültesi, Göğüs Hastalıkları Anabilim Dalı, \\ Balıkesir, Türkiye
}

Cite this article as: Sarıoglu N. Asthma and COVID-19: What do we know? Tuberk Toraks 2020;68(2):141-147.

\section{Yazıssma Adresi (Address for Correspondence)}

\section{Dr. Nurhan SARIOĞLU}

Balıkesir Üniversitesi Tıp Fakültesi, Göğüs Hastalıkları Anabilim Dalı, BALIKESIR - TÜRKIYE

e-mail: nurhangencer@hotmail.com

\begin{abstract}
Asthma and COVID-19: What do we know?

There are limited data about the coexistence of asthma and the Coronavirus disease-2019 (COVID-19). The COVID-19 pandemic is a new disease for the whole world. In this study, we aimed to examine the published case series with the COVID-19 and asthma coexistence, by reviewing existing studies and other publications. We discussed the suggestions of guidelines such as The Global Initiative for Asthma (GINA), The National Institute for Health and Care Excellence (NICE), and the Canadian Respiratory Guideline about the management of asthma during the COVID-19 pandemic and the experiences of different countries. We analyzed the publications, reports, and expert opinions about asthma and COVID-19, that were released and expressed from the onset of the disease in Wuhan. In this review, we aimed to summarize the approach to patients with asthma during the pandemic and to make recommendations concerning it.
\end{abstract}

Key words: Asthma; COVID-19; pandemic; treatment approach

ÖZ

\section{Astım ve COVID-19: Ne biliyoruz?}

Astım ve koronavirüs hastalığı-2019 (COVID-19) birlikteliği hakkında sınırlı sayıda veri bulumaktadır. COVID-19 pandemisi tüm dünyanın yeni tecrübe ettiği bir hastalıktır. Biz burada, astım ve COVID-19 ile ilgili yayınlanmış olan olgu serilerini ve varsa yapılmış çalışmaları ve diğer yazıları irdelemeye çalıştık. "The Global Initiative for Asthma (GINA)", "The National Institute for Health and Care Excellence (NICE)" ve "Canadian Respiratory Guideline" gibi rehberlerin COVID-19 pandemisi sırasındaki astım yönetimi konusundaki önerilerini ve farklı ülkelerdeki deneyimleri ele aldık. Hastalığın Wuhan'da ilk ortaya çıkışından bu güne kadar astım ve COVID-19 hakkında bildirilen yayınları, raporları ve uzman görüşlerini inceledik. Bu yazıda pandemi sırasında astım hastalarına yaklaşımı özetlemeye ve önerileri sunmaya çalıştık.

Anahtar kelimeler: Astım; COVID-19; pandemi; tedavi yaklaşımı 


\section{Introduction}

We receive new information about the disease every day, since the first diagnosis of the coronavirus in December 2019 in Wuhan. Currently, the whole world is still facing a serious pandemic and the fight against the disease is continuing. World Health Organization $(\mathrm{WHO})$ declared this outbreak as a pandemic on March 11, 2020, as the disease was spreading rapidly in many countries (1). While we are still learning new information about preventative measures for the mode of transmission; the treatment and vaccine studies are also continuing at full speed. Where do asthma patients stand in this pandemic? Is the coexistence of asthma and COVID-19 frequently observed? How the management of the patients with asthma in allergy \& asthma outpatient clinics should be during the pandemic? We tried to answer these questions in this study.

\section{Does Asthma Increase the Risk of COVID-19?}

Centers for Disease Control and Prevention (CDC) reported that individuals above 65 years old and those with chronic diseases were in the risk group for the COVID-19 (2). It was also reported that asthma patients with moderate to severe condition were in this risk group. However, the rate of asthma disease was low among the COVID-19 cases, especially in the observational case series from China. In a study evaluating the clinical characteristics and allergies of 140 patients from Wuhan, no cases of asthma and allergic rhinitis were reported; however, only 2 cases of urticaria were reported (3). In this study, the authors suggested that the prevalence of asthma and allergic rhinitis in Wuhan province was $4.2 \%$ and $9.7 \%$, respectively (4). They also stated that there might be unreported or undiagnosed asthma cases, and thus the prevalence may be higher. The authors came to the conclusion that asthma or allergies may not be risk factors for the COVID-19. In another study including 548 hospitalized cases in Wuhan, the risk factors were evaluated. The rate of asthma was reported to be $0.9 \%(n=5)$ among the comorbidities (5) (Table 1). The study put forward the hypothesis that IFN- $\gamma$, IL-1 $\beta$, IL-6, IL-8, IL-12, and TNF- $\alpha$ cytokines were secreted in COVID-19 depending on Th1 cell response, while Th2 immune response may be protective against the disease in asthma.

Different phenotypes of the disease were described in the article named "Eleven faces of coronavirus diseases 2019" (6). The article reported that an adult patient with the COVID-19 related pneumonia presented with urticaria for 2 years, a 2-year old child with pneumonia had a history of comorbid atopic dermatitis and a 3-year old child had the history of allergic rhinitis. Different phenotypes and clinical characteristics of 11 different patients were identified and there was no case with asthma reported.

In another series evaluating comorbidities in 1590 patients, no case of asthma was reported (7). These data were based on China-originated cases. The question comes to mind as to if these results differ in other countries? In a monthly report evaluating hospitalization and characteristics of cases in the USA, 180 comorbid diseases $(12.1 \%)$ among the 1482 hospitalized cases were reported (8). These were laboratory-confirmed cases, and among the 180 cases with comorbidities, the prevalence of asthma was reported as $17 \%$ and $27.3 \%$ in all age groups and in the $18-49$ age group, respectively. However, these are the rates among the comorbid diseases, and considering all

Table 1. Prevalance of asthma in patients with COVID-19

\begin{tabular}{|lcc|}
\hline Author & Asthma, $\mathbf{n}(\mathbf{\%})$ & All patients (n) \\
\hline Zhang JJ, et al. (3) & No & 140 \\
Li X, et al. (5) & $5(0.9)$ & 548 \\
Guan WJ, et al. (7) & No & 1590 \\
Garg S, et al. (8) & $27 / 159(17)$ & 1482 \\
Richardson S, et al. (9) & $479(9)$ & 5700 \\
Emami A, et al. (10) & No & 3403 \\
Williamson E, et al. (11) & $294.003(1.7)$ & 17.425 .445 \\
$\quad$ Present + recent ocs & $2.479 .371(14.2)$ & \\
\hline Present, no recent ocs & & \\
\hline * ocs: Oral corticosteroid. & & \\
\hline
\end{tabular}


hospitalized cases, the rate decreases significantly. The presence of asthma in the COVID-19 was reported as 9\% in the New York City area (9) (Table 1).

While some meta-analyses reported no data related to asthma (10), some others reported that asthma was related to a high risk of the COVID-19 mortality in hospitals (11). Moreover, in a 37-year old case with asthma and COVID-19, postmortem lung findings were reported (12). It was suggested that the patient had diabetes mellitus and was receiving ipratropium bromide and albuterol treatment for asthma. It is noteworthy that the patient was not using inhaler steroids. The existence of diffuse alveolar damage and mucous plaques in the patient's lung sections was associated with asthma.

Some authors explain the existence of only very few reports related to COVID-19 and asthma due to three possible reasons (13). First, some patients were underdiagnosed or there was poor recognition, particularly in China. Asthma might not have been reported in the hospital records of these patients. The second possibility is that a different immune response may occur in respiratory diseases. The third possibility is that medicines used in the treatment of chronic respiratory diseases (inhaled corticosteroids) may be protective against the COVID-19 or relieve the symptoms.

During in-vitro studies, it was indicated that pre-treatment administration of budesonide inhibited the HCov-229E replication and cytokine production in human respiratory epithelium (14). Furthermore, it was shown that ciclesonide blocked the Severe Acute Respiratory Syndrome Coronavirus 2 (SARS-CoV-2) RNA replication (15). There are also studies showing that inhaler steroids disrupt antiviral innate immune responses (16). Clinical trials that investigate the effectiveness of inhaler steroids in COVID-19 patients are ongoing (see https://clinicaltrials.gov).

\section{Do Asthma and Allergies or Their Treatment Affect ACE2 Receptor Gene Expression in The Airway?}

The SARS-CoV-2 enters into the cell by binding to ACE2 receptors. The levels of ACE2 gene expression in patients with asthma were studied $(17,18)$. ACE2 gene expression was calculated from total RNA via nasal epithelium irrigation, in 11-year-old children $(n=318)$ who were monitored since their birth according to phenotypic traits in Environment and
Childhood Asthma (URECA) cohort group (17). Levels of Type 2 biomarkers, which are fractional exhaled nitric oxide (FeNO), total IgE, and blood eosinophils, were also evaluated. It was also identified that allergic sensitization was inversely correlated to ACE2 expression in the nasal epithelium. Additionally, it was proven that there was a significant negative correlation between Type 2 biomarkers (specific IgE, Total IgE, FeNO) and nasal epithelial IL-13 expression and ACE2 expression. Nasal allergen challenge test and allergen bronchoprovocation tests were performed with sensitive allergen and it was shown that ACE2 expression decreased after the exposure to the allergen (17).

In allergic asthma, decreased levels of receptors in host to which the SARS-CoV-2 binds may provide protection against the disease. Further detailed studies on Type 2 immune modulation in the COVID-19 pathogenesis are needed.

The second study provides important information on the relationship between asthma, ICS, and ACE2 expression (18). Peters and investigators of Severe Asthma Research Program-3 (SARP-3), have demonstrated that the use of inhaled corticosteroids is associated with a decreased level of ACE2 and transmembrane protease serine 2 (TMPRSS2) gene expression from sputum in asthmatic patients (18). These results are promising; however, they should be confirmed by larger prospective studies.

\section{Does the SARS-CoV-2 Cause an Asthma Attack?}

Today, there is no proof or data answering this question. It is known that respiratory tract viruses can cause an asthma attack. In previous studies, it was reported that respiratory tract viruses such as rhinovirus (RV), respiratory syncytial virus (RSV), herpes simplex virus, enterovirus (EnV), influenza (IfV) were the viruses most frequently causing asthma attacks (19). It was observed that non-pandemic coronaviruses also caused asthma attacks, though less frequently. There was no relation between previous pandemic coronaviruses (SARS-CoV and MERS-CoV) and asthma attacks (19).

It was previously demonstrated that azithromycin increased IFN- $\beta$ and IFN- $\lambda$ production in human bronchial epithelial cells infected with the rhinovirus $(20,21)$. It was reported that antiviral IFN production in the respiratory cells infected with the virus may 
play a vital role in host defense in the antiviral innate immunity against the SARS-CoV-2 (22). There are also clinical studies showing that azithromycin prevents virus-induced asthma attacks (23). Therefore, it was proposed to use azithromycin at a low dose in the treatment of asthma patients, whose conditions cannot be controlled despite appropriate treatment, to prevent severe consequences of the COVID-19 (22).

\section{How Should Be The Management of Asthma Patients During The Pandemic?}

Guidelines and experts suggest that asthma patients continue taking their inhaler corticosteroids and add on treatments during the pandemic (24-27). It is recommended to avoid the use of nebulizers in hospitals due to the risk of transmitting the disease to healthcare providers and other patients, and not to perform spirometry, if not necessary. Use of a metered-dose inhaler (MDI), and a spacer with a mouthpiece or a tightly fitting face mask is advised instead of nebulizer treatment in asthma attacks (24).

However, adequate inspiratory flow may not be available in acute respiratory failure. Some experts recommend using nebulizers with a mouthpiece or high flow nasal cannula to be considered in such cases (28). The placement of filter to the nebulizer has been shown to be effective in capturing exhaled aerosol droplets (28-30). The filters lead to reduce the transmission of aerosols to the environment. Mesh nebulizers can also be preferred instead of the jet nebulizers (28). These recommendations should be considered in the treatment of patients with COVID19 and asthma.

For mild asthma patients or those with asthma under control, there is an opinion to postpone routine check-up visits and inform them via phone calls, e-mail, or text message instead (24-27). Hospital visits of these patients are undesirable due to the risk of the COVID-19 transmission. Face-to-face visits of patients who have been well controlled and without an emergency visit in the last 6-12 months and who have received $\leq 1$ of oral steroid in tha past 6 months may be postponed. These patients may be managed remotely via telehealth service (27).

Patients who have an attack in the last 3-6 months and who have a history of an emergency visit or hospitalization should be prioritized. The COVID19 screening protocol should be applied to the patients admitted with worsening asthma or acute attack, and the risk of the SARS-CoV-2 infection and the necessity of testing should be questioned (27). The SARS-CoV-2 is a highly contagious virus, and healthcare workers must comply with the protection and isolation measures.

A clinician working in an asthma and allergy department should always bear in mind that allergic rhinitis, asthma, viral upper respiratory tract infections may coexist with the symptoms of COVID-19-related upper respiratory tract infection (27).

\section{Use of Systemic Corticosteroids for Asthma Attacks}

The use of systemic steroids in COVID-19 related lung injury has been controversial. There are concerns that prednisolone may prolong viral replication. Chinese Thorax Society advocates that short term use of systemic steroids at low doses $(\leq 0.5-1$ $\mathrm{mg} / \mathrm{kg}, \leq 7$ days) is beneficial for COVID-19 related lung injury (31). Russel et al. stated that the use of systemic steroids in the SARS-CoV and MERS-CoV infections, delayed the clearance of viral RNA from the respiratory tract, caused various side effects, and there was no clinical evidence to support the use of steroid treatment in the COVID-19 (32).

The use of systemic steroids in asthma attacks (mostly triggered by viral infections) is a treatment method commonly found in classic guidelines. Today, the relation between the COVID-19 and asthma attacks has not been clarified yet. The Global Initiative for Asthma (GINA) encourages the use of oral steroids for mild attacks during the pandemic, as it decreases the rate of hospitalizations (24). Canadian Society suggests the use of systemic steroids in asthma attacks, whether they are COVID-19 related or not (26). Protecting the patients against asthma attacks is essential during this period. Elevating the inhaler steroid dose of the patients may prevent them from having an attack $(24,27)$. Giving patients a written action plan and following up via remote telemedicine are suitable approaches during this period $(24,27)$.

Levin et al. have reported acute asthma management protocol for clinicians during the COVID-19 pandemic (33). They suggest that high dose MDI and rapid initiation of systemic corticosteroids could prevent the worsening of asthma attacks. 


\section{Biological Treatments}

Recent guidelines suggest continuing the use of biological agents during the pandemic period. There is no evidence indicating that biological agents suppress the immune response to a viral infection. It is known that these treatments used in severe cases of asthma reduce asthma attacks (24-27). It was shown in a randomized controlled study conducted in children between the ages of 9 and 17, who had allergic asthma, that omalizumab lowered the viral shedding and the duration of rhinovirus, the most commonly identified virus in asthma attacks (34).

FDA has approved omalizumab for short term home administration during the COVID-19 pandemic (35). In different countries, their national guidelines encourage the use of biological treatments as homebased administration during a pandemic (25,35-37).

Clinical trials conducted with omalizumab, mepolizumab, reslizumab, benralizumab, and dupilumab, showed that these drugs did not increase the risk of getting a viral infection, but reduced asthma exacerbations (38-42). In the light of current information, we should continue these treatments in patients with severe asthma during the pandemic.

The challenge is to decide whether these drugs should be continued under a COVID-19 therapy. Randomized controlled trials involving treatments against the COVID-19 have focused on the use of hydroxychloroquine, chloroquine, azithromycin, antivirals, and immune or recovery plasma, as well as anti-IL-6. These drugs can be compatible with biologics in severe asthma; however, there is no available data yet. The decision of postponing a biologic agent until a patient recovers or maintaining it should be based on a case-by-case evaluation supported by a multidisciplinary council (43).

\section{Conclusion}

Keeping asthma under control during the pandemic is the best protection against COVID-19. Medicines used in the treatment of asthma such as inhaler steroids (either alone or combined) and biological agents, should be continued. Guidelines and experts have expressed their opinions in this direction.

\section{CONFLICT of INTEREST}

The author reported no conflict of interest related to this articles.

\section{REFERENCES}

1. World Health Organization. WHO Director-General's opening remarks at the media briefing on COVID-19- 11 March 2020. Available from:https:// www.who.int/dg/ speeches/detail/ who-director-general-s-opening-remarksat-the-media-briefing-on-covid-19---11-march-2020, Accessed $15^{\text {th }}$ Mar 2020

2. Centers for Disease Control and Prevention. Coronavirus disease 2019 (COVID-19) situation summary Available from: https://www.cdc.gov/coronavirus/2019-ncov/ index.html, Accessed 15th Mar 2020

3. Zhang J, Dong X, Cao YY, Yuan YD, Yang YB, Yan YQ, et al. Clinical characteristics of 140 patients infected with SARSCoV-2 in Wuhan, China. Allergy 2020. doi: 10.1111/ all. 14238 .

4. Huang $K$, Yang $T, X u$ J, et al. Prevalence, risk factors, and management of asthma in China: a national cross-sectional study. Lancet 2019;394:407-18.

5. Li X, Xu S, Yu M, Wang K, Tao Y, Zhou Y, et al. Risk factors for severity and mortality in adult COVID-19 inpatients in Wuhan. I Allergy Clin Immunol 2020 pii: S00916749(20)30495-4

6. Dong $X$, Cao $Y Y, L u X X$, Zhang $J$, Du $H$, Yan YQ, et al. Eleven faces of coronavirus disease 2019. Allergy 2020. doi: 10.1111 /all.14289.

7. Guan WJ, Liang WH, Zhao Y, Liang HR, Chen ZS, Li YM, et al. Comorbidity and its impact on 1590 patients with COVID-19 in China: a nationwide analysis. Eur Respir J 2020;55(5).pii: 2000547. doi: 10.1183/13993003.005472020

8. Garg S, Kim L, Whitaker M, O'Halloran A, Cummings C, Holstein $R$, et al. Hospitalization rates and characteristics of patients hospitalized with laboratory-confirmed coronavirus disease 2019 - COVID-NET, 14 States, March 1-30, 2020. MMWR Morb Mortal Wkly Rep 2020;69(15):45864. doi: 10.15585/ mmwr.mm6915e3.

9. Richardson S, Hirsch JS, Narasimhan M, Crawford JM, McGinn T, et I. Presenting characteristics, comorbidities, and outcomes among 5700 patients hospitalized with COVID-19 in the New York City area. JAMA 2020. doi: 10.1001/ jama.2020.6775

10. Emami A, Javanmardi F, Pirbonyeh N, Akbari A. Prevalence of underlying diseases in hospitalized patients with COVID-19: a systematic review and meta-analysis. Arch Acad Emerg Med 2020;8(1):e35. eCollection 2020.

11. Williamson E, Walker AJ, Bhaskaran K, Bacon S, Bates C, Morton CE, et al. OpenSAFELY: factors associated with COVID-19-related hospital death in the linked electronic health records of 17 million adult NHS patients. COVID19 SARS-CoV-2 preprints from medRxiv and bioRxiv 2020 doi: 10.1101/2020.05.06.20092999

12. Konopka KE, Wilson A, Myers JL. Postmortem lung findings in an asthmatic with coronavirus disease 2019 (COVID 19). Chest 2020 pii: S0012-3692(20)30775-3. doi: 10.1016/j.chest.2020.04.032 
13. Halpin DMG, Faner R, Sibila O, Badia JR, Agusti A. Do chronic respiratory diseases or their treatment affect the risk of SARS-CoV-2 infection? Lancet Respir Med 2020;8(5):436-8.

14. Yamaya $M$, Nishimura $H$, Deng $X$, Sugawara $M$, Watanabe $O$, Nomura K, et al. Inhibitory effects of glycopyrronium, formoterol, and budesonide on coronavirus HCoV-229E replication and cytokine production by primary cultures of human nasal and tracheal epithelial cells. Respir Investig 2020. Epub 2020/02/26.

15. Matsuyama S, Kawase $M$, Nao N, Shirato K, Ujike $M$, Kamitani W, et al. The inhaled corticosteroid ciclesonide blocks coronavirus RNA replication by targeting viral NSP15. bioRxiv 2020. doi: 10.1101/2020.03.11.987016

16. Simpson IL, Carroll M, Yang IA, Reynolds PN, Hodge $S$, James $A L$, et al. Reduced antiviral interferon production in poorly controlled asthma is associated with neutrophilic inflammation and high-dose inhaled corticosteroids. Chest 2016;149(3):704-13.

17. Jackson DJ, Busse WW, Bacharier LB, Kattan M, O'Connor GT, Wood RA, et al. Association of respiratory allergy, asthma, and expression of the SARS-CoV-2 receptor ACE2. J Allergy Clin Immunol 2020 pii: S0091-6749(20)30551o. doi: 10.1016/j.jaci.2020.04.009

18. Peters MC, Sajuthi S, Deford P, et al. SARS-COV-2 related genes in sputum cells in asthma: relationship to demographic features and corticosteroids. Am J Respir Crit Care Med 2020. doi: 10.1164/rccm.202003-0821OC.

19. Zheng $X Y, X u Y J$, Guan WJ, Lin LF. Regional, age and respiratory-secretion-specific prevalence of respiratory viruses associated with asthma exacerbation: a literature review. Arch Virol 2018;163(4):845-53.

20. Gielen V, Johnston SL, Edwards MR. Azithromycin induces anti-viral responses in bronchial epithelial cells. Eur Respir J 2010;36(3):646-54.

21. Porter JD, Watson J, Roberts LR, Gill SK, Groves H, Dhariwal J, et al. Identification of novel macrolides with antibacterial, anti-inflammatory and type I and III IFNaugmenting activity in airway epithelium. I Antimicrob Chemother 2016;71(10):2767-81.

22. Johnston SL. Asthma and COVID-19: is asthma a risk factor for severe outcomes? Allergy 2020. doi: 10.1111/ all. 14348 .

23. Gibson PG, Yang IA, Upham IW, Reynolds PN, Hodge S, James $A L$, et al. Effect of azithromycin on asthma exacerbations and quality of life in adults with persistent uncontrolled asthma (AMAZES): a randomised, doubleblind, placebo-controlled trial. Lancet 2017;390(10095):65968.

24. Global Initiative for Asthma. Global Strategy for Asthma Management and Prevention. Available from: www. ginaasthma.org

25. COVID-19 rapid guideline: severe asthma. NICE guideline [NG 166]Published date: 03 April 2020.
26. Licskaia C, Yang CL, Ducharmec FM, Radhakrishnand D, Podgerse D, Ramseyf $C$, et al. Addressing therapeutic questions to help Canadian physicians optimize asthma management for their patients during the COVID-19 pandemic. Canadian J Respir Crit Sleep Med Available from: https://doi.org/10.1080/ 24745332.2020.1754027

27. Shaker MS, Oppenheimer J, Grayson M, Stukus D, Hartog N, Hsieh EWY, et al. COVID-19: pandemic contingency planning for the allergy and immunology clinic. I Allergy Clin Immunol Pract 2020;8(5):1477-88.e5.

28. Ari A. Practical strategies for a safe and effective delivery of aerosolized medications to patients with COVID-19. Respir Med 2020:105987. doi: 10.1016/j.rmed.2020. 105987

29. McGrath J, O'Toole C, Joyce GBM, Byrne M, MacLoughlin $R$. Investigation of fugitive aerosols released into the environment during high-flow therapy. Pharmaceutics 2019; 11:254.

30. Wittgen BP, Kunst PW, Perkins WR, Lee JK, Postmus PE. Assessing a system to capture stray aerosol during inhalation of nebulized liposomal cisplatin. I Aerosol Med 2006;19:385-91.

31. Shang L, Zhao J, Hu Y, Du R, Cao B. On the use of corticosteroids for 2019-nCoV pneumonia. Lancet 2020;395(10225):683-4

32. Russell CD, Millar JE, Baillie JK. Clinical evidence does not support corticosteroid treatment for 2019-nCoV lung injury. Lancet 2020 Feb 15;395(10223):473-5.

33. Levin M, Morais-Almeida M, Ansotegui IJ, Bernstein J, Chang YS, Chikhladze $M$, et al. Acute asthma management during SARS-CoV2-pandemic 2020. World Allergy Organ J 2020 May 14:100125. doi: 10.1016/j.waojou.2020.100125.

34. Esquivel A, Busse WW, Calatroni A, Togias AG, Grindle $K G$, Bochkov YA, et al. Effects of omalizumab on rhinovirus infections, illnesses, and exacerbations of asthma. Am J Respir Crit Care Med 2017;196(8):985-92.

35. Self-Administration of Xolair Pre-Filled Syringe (PFS) for Asthma during the COVID-19 Pandemic. https://www. gene.com/medical-professionals/medicines/xolair. Accessed 23-Apr-2020

36. http://www.siaaic.org/wp-content/uploads/2020/04/ Documento-di-Indirizzo-SIAAIC.pdf. Accessed 8-Apr-2020.

37. Malipiero G, Paoletti G, Puggioni F, Racca F, Ferri S, Marsala $A$, et al. An academic allergy unit during COVID-19 pandemic in Italy. I Allergy Clin Immunol 2020 Apr 16:S00916749(20)30489-9. doi: 10.1016/j.jaci.2020.04.003

38. Mitchell P, Leigh R. A drug safety review of treating eosinophilic asthma with monoclonal antibodies. Expert Opin Drug Saf 2019;18(12):1161-70.

39. Agache I, Rocha C, Beltran J, et al. Efficacy and safety of treatment with biologicals (benralizumab, dupilumab and omalizumab) for severe allergic asthma. Allergy $2020 \mathrm{Feb}$ 16. doi: 10.1111/all.14235. 
40. Pavord ID, Korn S, Howarth P, et al. Mepolizumab for severe eosinophilic asthma (DREAM): a multicentre, double-blind, placebo-controlled trial. Lancet 2012;380(9842):651-9.

41. FitzGerald IM, Bleecker ER, Nair P, et al; CALIMA study investigators. Benralizumab, an anti-interleukin-5 receptor a monoclonal antibody, as add-on treatment for patients with severe, uncontrolled, eosinophilic asthma (CALIMA): a randomised, double-blind, placebo-controlled phase 3 trial. Lancet 2016;388(10056):2128-41.
42. Castro M, Corren J, Pavord ID, et al. Dupilumab efficacy and safety in moderate-to-severe uncontrolled asthma. $N$ Engl I Med 2018;378(26):2486-96.

43. Morais-Almeida M, Aguiar R, Martin B, Ansotegui IJ, Ebisawa M, Arruda LK, et al. COVID-19, asthma, and biologic therapies: What we need to know. World Allergy Organ J 2020 May 16:100126. doi: 10.1016/j.waojou.2020.100126. 